\title{
The influence of environmental temperatures and air humidity in the maintenance of the sterility of materials sterilized in different wraps
}

\author{
CQDM Bruna*, KU Graziano, FM Gomes Pinto \\ From International Conference on Prevention \& Infection Control (ICPIC 2011) \\ Geneva, Switzerland. 29 June - 2 July 2011
}

\section{Introduction / objectives}

One of the variables which interfere in the maintenance of sterility in the materials is the storage. There are many official and not-official recommendations for temperature and air humidity control in the storage area, however without any theoretical or experimental basis. Some hospitals do not have a system that makes the control of temperature and humidity possible, and, in most cases, the sterilizing chambers are next to the storage area, constantly releasing heat and water vapour. Considering that one of the functions of the wraps is to maintain the sterility of the content, even under adverse conditions, the recommendations to have an environmental control in the storage area, a priori, would have a secondary importance. For these reason the doubt about the real importance of the temperature and humidity in the contamination of the materials stored after the autoclave sterilization arise.

\section{Methods}

Therefore, an experiment was developed in which boxes with surgical instruments and cylinders carriers were packed in cotton sheets, crepe paper, SMS and surgicalgrade paper, sterilized, and intentionally contaminated externally with Serratia marcescens $10^{6}$ and stored in an environment with temperature around $35^{\circ} \mathrm{C}$ and air humidity around $75 \%$. This group was compared with another group, the negative control, stored in temperature around $20{ }^{\circ} \mathrm{C}$ and air humidity around $60 \%$. After a period of 30 days of storage, the carriers were removed from the boxes and incubated.

Escola de Enfermagem, Universidade de São Paulo, São Paulo, Brazil

\section{Results}

No bacterial growth was detected in any of the samples.

\section{Conclusion}

The experiment results allowed concluding that the high temperature and high air humidity do not interfere in the barrier efficiency of the packs.

\section{Disclosure of interest}

None declared.

Published: 29 June 2011

doi:10.1186/1753-6561-5-S6-P311

Cite this article as: Bruna et al:: The influence of environmental

temperatures and air humidity in the maintenance of the sterility of materials sterilized in different wraps. BMC Proceedings 2011 5(Suppl 6): P311.

Submit your next manuscript to BioMed Central and take full advantage of:

- Convenient online submission

- Thorough peer review

- No space constraints or color figure charges

- Immediate publication on acceptance

- Inclusion in PubMed, CAS, Scopus and Google Scholar

- Research which is freely available for redistribution 